\title{
7. Hank, My Mentor
}

\author{
Keiko Tamura
}

Keiko Tamura completed her PhD under Hank Nelson's supervision in 1999 and has held research positions at ANU, Kobe University and Kyoto University. She is a visiting fellow in the School of Culture, History and Language at ANU.

A message from Bill Gammage on Hank's passing reached me in Kobe on 18 February 2012. It was a bright and sunny day, but cold and clear. Occasionally white snowflakes danced down from the blue sky, glittering in the sunshine. From my hotel room on the 8th floor, I could see the Rokko Range clearly in the north of Kobe. Downward gaze spotted locals and tourists milling in the narrow streets of the Chinatown. They were shopping, eating tasty delicacies and chatting among themselves. I could almost hear the noise and smell the food down there. But I did not want to mingle with the crowd. I stayed in my room, as I felt immense sadness that Hank was no more. Even though we all knew that was imminent because of his declining health, I was still shocked when it finally happened. I have been reflecting on my engagement with Hank, which spanned over two decades. Although the sadness and sense of loss are still with me, I feel I was so lucky and privileged to get to know him, first as a respected academic, then as my supervisor and as a colleague over that period. I always ask myself, 'What Hank would say?' when I wonder what I should do.

My first encounter with Hank was totally uninspiring, solely due to my blunder. Then his presence gradually grew bigger in my academic career. Before I realised it, he was my mentor, to whom I always turned when I needed some crucial advice. Sometimes he gave a decisive and definite response and advised me to tackle the issues. Sometimes he just listened and waited until I decided for myself. What stays with me is his smile whenever I told him about some exciting news, discoveries or plans. He was happy to share good news with me but not overly emotionally involved when not-so-good news was shared. Over two decades, Hank became my confidant.

I saw Hank for the first time in the early 1990s when I went along to his lecture on Rabaul at the Australian War Memorial. I do not remember why I decided to attend the talk because my interest in the Pacific War had not developed at all then. Rather, I was actively avoiding anything to do with the war. On the day I saw Hank for the first time, he entered the lecture venue with a shy smile, walking with crutches (after injuring his leg playing tennis, I later found out from him). His trademark moustache reminded me not of Henry Lawson, as my Australian colleagues would say, but of Nigel Mansell, a champion British 
Formula One driver whom I was a big fan of around that time. During the talk, alas, I started to nod off, only to be woken by a sudden shudder as someone behind me knocked the chair leg with his foot. I woke up with a shock and felt awfully embarrassed but at the same time annoyed with this presumably militaristic method of handling the sleepy audience. I told myself never to attend any talks at the Memorial in the future, and I never imagined that I would form a long association with the Memorial several years later through working for the Australia-Japan Research Project. As for Hank's lecture, I cannot remember what he talked about.

The next encounter with Hank was in August 1991 when I first learned about the issues on the Australian prisoners of war. I attended a seminar on the Thai-Burma Railway that was co-hosted by Hank and Gavan McCormack. ${ }^{1}$ The seminar brought together not only Australian and Japanese historians but also a group of Australian ex-POWs and a former camp guard of Korean descent. The Australian POWs included Edward (Weary) Dunlop, Tom Uren and Hugh Clark. The Korean ex-guard, Yi Hak-Nae, travelled to Canberra because he wanted to apologise directly to the Australians for his conduct.

My lack of knowledge on the topic was mainly because I belong to the post-war generation of Japanese who grew up during the 'economic miracle' period. At school we received the so-called 'peace education', where the importance and virtue of peace were drummed into us. It was a fairly simple binary ideology: peace was good, and war was evil. Let us talk about peace, but don't talk about war. Throughout my schooling, it was almost a taboo to learn about the Pacific War. For us, the war started with the Japanese attack on Pearl Harbor in December 1941 and ended in August 1945 after two atomic bombs in Hiroshima and Nagasaki, but what happened in between was not clear. We did not learn how the China-Japan war had started in 1937 or how and why the Japanese troops fought miserable battles in New Guinea and surrounding islands. As for the prisoners of war, I had heard of the film The Bridge on the River Kwai. For me the film was simply one of many Western war movies with a catchy theme tune, 'Colonel Bogey March'. I was not interested in those war films as the Japanese depicted in them were never favourable - rather ugly and fanatic. My knowledge gap was actually much wider. I am embarrassed to confess that I did not even know that Australia fought against Japan in the Pacific War until I came to Australia. For Japanese, the Pacific War was the war between Japan and the United States. I learned about Australia's involvement only when I started to work as a Canberra tour guide for Japanese tourists when I was a student. During visits to the Australian War Memorial with young Japanese honeymooners, I happily recited the Japanese submariners' bravery in the

1 See Gavan McCormack and Hank Nelson (eds), The Burma-Thailand Railway: Memory and History, St Leonards, NSW: Allen \& Unwin, 1993. 
Sydney attack and pointed out some Japanese good luck flags in order to stir up their emotions, but I made sure to avoid any objects that showed the cruelty carried out by the Japanese. I simply was not sure how I could tell those dark stories to the Japanese visitors.

The 1991 seminar on the Thai-Burma Railway revealed to me many stories that were horrific. I felt ashamed to learn about the inhumane treatment of the prisoners by the Japanese military. At the same time, I was moved by the gracious acceptance by Edward Dunlop of Yi Hak-Nae's apology. In contrast, Tom Uren and some other POWs told Yi that they understood his intention but could not accept the apology, which made me realise how deeply they were scarred by the experience. Hank's contribution was felt, but for me it was overwhelmed by other emotive impacts. At the end, I regarded the seminar as an interesting and stimulating intellectual experience, but I was not ready to be involved in further painful issues of war. It took me another several years before engaging with these issues under the guidance of Hank.

I started my PhD research on Japanese war brides in 1993 with a scholarship, after a few previous false starts. Nic Peterson (Department of Archaeology and Anthropology) and Gavan McCormack were appointed as my supervisors. I approached Hank to be on my panel as an advisor, and he agreed readily. My research method was rather unusual for $\mathrm{PhD}$ research in anthropology, where research students usually spend up to 18 months carrying out fieldwork away from the university. Instead, I was going to collect the research data through a series of life story interviews with the war brides in conjunction with archival research. I framed this research plan so that I did not need to move away from Canberra since my two sons were still young then. What I was hoping for from Hank was his expertise in oral history research. Our association started finally, and how lucky I was to learn so much from him.

Throughout my PhD years, Hank was the one from whom I drew intellectual and moral support most. I received much advice and wisdom from him during these years. One of the first things he said to me was, 'You will start receiving Christmas cards from your informants'. Another was, 'Don't write a thesis; write a book', as other ex-students of his have testified. He also wanted his students to have a prospective reader in mind. As Margaret Reeson has written, his suggestion was a matron in Broome Hospital. It took me some time to figure out what he meant by these pieces of advice, but later they all made sense. The significance of receiving Christmas greetings from the informants meant building personal trust and respect with them. The generation of women I interviewed expressed these sentiments by putting me on their Christmas greeting lists as the Australian ex-POWs must have done for Hank. I found an equivalent of the Broome Hospital matron in Jude Shanahan, one of the long-term administrators of the Division of Pacific and Asian History. She was intelligent and curious but 
not an expert in particular subjects. She was always ready to hear the progress and appreciate my research findings. As Hank said, I did receive Christmas cards from Japanese war brides for many years, and part of my thesis was published as a book in $2001 .^{2}$

For my PhD research, Hank's understanding of Australian servicemen and their culture was indispensable. The men who were too young during the Pacific War went to Japan as members of the British Commonwealth Occupation Force (BCOF), met Japanese women, fell in love and brought them back to Australia. Hank remembered the arrival of Cherry Parker, the first Japanese war bride in Australia, in 1952. These were the insights that I could not learn from books and archival material. Yet the most significant insight Hank gave me was in understanding why the women decided to tell their stories and how they talked about their experiences, as Hank's work on the Australian POWs shared common factors with my research.

Hank and Tim Bowden worked on the major oral history project on Australian POWs for the Australian Broadcasting Corporation in 1984. The 16-part radio series and subsequent book by Hank significantly influenced how Australia remembers and commemorates the POWs and their experiences. My PhD project, although much smaller in scale, had some similarities. The ex-POWs and Japanese war brides started to tell their stories in the public sphere in their old age after many years of silence. At the beginning of their research, Hank and Tim attended the 40th anniversary national reunion of ex-POWs in 1981 in order to establish contacts. Then the next year they travelled to Thailand with the veterans. The start of my research also coincided with the 40th anniversary gathering in Melbourne to celebrate the Japanese war brides' arrival in Australia. I subsequently travelled to Hawai' $i$ with the women when they joined a larger group of Japanese war brides who had married US servicemen. These interactions allowed researchers to meet and recruit the informants, while the informants themselves could measure the researchers for their worth. Another important common factor was the content and timing of their narratives. While the nature of Japanese war brides' experiences was significantly different from the POWs', both groups shared the feeling that other people who had not lived through the same experience would not understand. The women's stories were filled with the personal anguish of dislocation and the sense of isolation in the new country. They were also conscious of the social stigma towards them in Japan, where people questioned their marital motivation. The women were reluctant to talk publicly for fear of being misunderstood, just as the POWs had been. Like the ex-POWs, the women did not tell their stories to their children, partly due to their lack of English fluency but mainly due to their concern about

2 Keiko Tamura, Michi's Memories: The Story of a Japanese War Bride, Canberra: Pandanus Books, 2001. (Reprinted in 2011 by ANU E Press.) 
whether the children would understand and appreciate them. In order to avoid the disappointment of being misunderstood, both groups were very hesitant to open up to outsiders. Yet as they reached their old age and had time to reflect on their lives, they started to make sense of what happened and its consequences. Hank was generous to share his expertise and gently guided me to explore why the women started to tell their stories to a researcher when they had not even told them to their own families.

When I started to write the women's life stories in my thesis chapters, Hank became a keen and responsive reader. His comments were generally encouraging yet at the same time included always some difficult tasks that I needed to work on. I kept his note from 24 April 1998 for one of the war brides' stories. Here he wrote,

Keiko, You are going to write a good book. The life stories are excellentengaging, amusing, disturbing. The more detail you can fit in the better. You are aiming for frank, conversational prose - prose (as you are aware) that reflects personality and social status.

I remembered I was so happy to read his encouraging words but at the same time wondered how I should produce convincing English prose when the original interviews were carried out in Japanese. Some details I wanted to include were appreciated by Hank greatly. For example, I wrote how a Japanese grandfather handled his 'mixed-blood' grandson. His teenage daughter had fallen in love with an Australian man in Tokyo, eloped to marry him without parental consent and gave a birth to a son. When she was hospitalised for TB treatment, the young son was sent to her parents. The grandfather was initially reluctant to accept the boy because the mixed-blood baby would be a source of embarrassment in the neighbourhood, but he gradually became attached to his grandson. He carried him on his back for walks at night although he made sure the boy wore a hat to hide his light-coloured hair. Hank told me that he found the grandfather's reaction so interesting that he read that section out to his wife, Jan. For me, that was one of the best compliments I received from Hank.

In 1997, the Australia-Japan Research Project was established at the Australian War Memorial with substantial funding from the Japanese government. The project was to promote research and understanding of the war history between Japan and Australia through research database construction and bilingual publications on the internet. With Hank's recommendation, I applied for a research position and got it. In hindsight, that was the turning point of my research career. Over the next 13 years, the project evolved and covered a wide range of topics such as Australian and Japanese soldiers' experiences in New Guinea, the Cowra Breakout and the aftermath of the Japanese midget submarine attack in Sydney. Through my work on the project, I gradually 
accumulated knowledge and understanding on the war. My initial avoidance in dealing with war started to change to realisation that these were the important issues to study.

In December 2001, a symposium on the Pacific War in Papua New Guinea was held at Rikkyo University in Tokyo. Hiromitsu Iwamoto, Hank's ex-student and one of the symposium organisers, invited me and Hank to Tokyo. Hank was accompanied by Jan, and other members included Bryant Allen from ANU and Peter Stanley and Peter Londey from the Australian War Memorial. I was asked to act as a tour conductor to deliver the Australian delegation from Canberra to the university in Ikebukuro. For Hank, it was his second visit to Japan. We flew from Sydney to Narita and caught an airport bus to Ikebukuro; then we realised that nobody was there to meet us at the coach terminal. Instead of waiting around, Hank and Jan decided to set off for the hotel with some others. Bryant, a human geographer, was given the task of reading the local map. When I eventually arrived at the hotel some time later, the first group was nowhere to be seen, and hastily a search party was sent out. It turned out that the hotel was located on a discreet back street of Ikebukuro's red-light district and was rather difficult to find.

The symposium went smoothly in spite of this adventure at the beginning. I presented a paper on the Japanese military nurses in Rabaul and invited one of the ex-nurses, Mitsu Sakata, to the symposium. Hank and Mrs Sakata felt mutual affinity instantly during the reception. Although neither of them spoke the other's language, somehow the Rabaul connection seemed to draw them together. Mrs Sakata treasured for many years a silk scarf that Hank presented to her. Hank and Jan extended their stay to explore Tokyo. By the time they returned to Canberra, he was so proud that they could manage to find their way around in the complex Tokyo transport system, particularly the Yamate Loop Line.

Hank maintained neutral attitudes on Japan even though his research on the POWs had a lot to do with the country and its people. He must have heard horrific stories of mistreatment of the ex-POWs under Japanese control, but those stories did not seem to affect negatively his attitudes to the country and its people. Hank and Tim Bowden initially expected the ex-POWs to talk a lot about their sentiments towards and interactions with the Japanese soldiers, but the Australians were more interested in talking about their relationships with other POWs. Hank never asked me to explain why the Japanese soldiers and their colonial camp guards had behaved in such brutal ways to the POWs. Neither did he try to explain their behaviour from cultural relativism. He was open to and friendly with the Japanese researchers. Over the years, I introduced many of my Japanese colleagues to Hank. Since his POW book had been translated into Japanese and was widely read, they usually expected to meet an authoritative figure who might make some moral judgements on Japan and its military. On 
the contrary, they were surprised when they met a humble academic with a shy but friendly smile. He treated them with openness and engaged in discussion without making any judgement on Japan.

I had a chance to work closely with Hank when we organised an international symposium on the POW experience at ANU in August 2006. The symposium, 'Towards Better Understanding: Reflections on the Experiences of Australian Prisoners of War of the Japanese', was jointly hosted by the Division of Pacific and Asian History, ANU, and the POW Research Network Japan (the Network). The Network is a Japanese group whose members come from variety of backgrounds in academia, journalism and education. The members are involved in research on POWs and a reconciliation movement. Aiko Utsumi, who took part in the 1991 ANU POW seminar, was one of the representatives of this energetic organisation. I was contacted by the Network for the possibility of organising a symposium in Australia so that not only Australian and Japanese researchers could present their papers, but also some Australian ex-POWs would attend and discuss their experiences for the international audience. I went to see Hank for his opinion when I received the enquiry. His response was short and definite. He pointed out that the average age of surviving ex-POWs was already 86 years old, and we should not wait too long before organising such a symposium. Although I knew it was going to be a daunting task to host a symposium, his conviction motivated me. The two-person local committee started its work. Hank provided me with moral and intellectual support throughout the preparation period.

The symposium was a success. Twelve members of the Network travelled from Japan to Canberra, and several of them presented their research papers. Australian and New Zealand researchers presented their research. With Hank's advice, we invited Rowley Richards, a prominent medical doctor and ex-POW who had had the 'full tour' as a POW since he was captured in Singapore, sent to the Thai-Burma Railway and then transported to Japan, including the sinking of the transport ship on the way. He spoke about his experiences and his stern views on Japan. Several ex-POWs attended the symposium with their family members. For some families, it was the first time to hear their fathers talk of their war experiences. I believe one of the main reasons for its success was Hank's involvement. His paper, 'Australian Perceptions of the POWs of Japan', opened the symposium and set the scene. The participants felt confident that a symposium in which Hank Nelson took part would be worthwhile.

I returned to Australia from Japan on the day of Hank's public memorial at University House. A long queue at passport control in Sydney Airport caused a long delay, and I missed the connection to my scheduled domestic flight. When I finally arrived at the Common Room, proceedings had already started. The room was filled with people, and many speeches were delivered, but for me the most memorable event was Ted Egan's singing of 'Sayonara Nakamura' at 
the end. The song is about a young Okinawan pearl diver named Nakamura, who died of bends off Broome, and it was chosen by Hank to be played in the private funeral that had already taken place. Ted Egan, who happened to be in Canberra when Hank died, wanted to attend the memorial gathering. When he learned that his song was played at the funeral, he offered to sing the song at the memorial. Ted sang solo beautifully without any musical accompaniment. While I was listening to the song, I could picture the sea, the pearling lugger and the diving gear divers wore, from my visit to Broome. The song laments the loss of young life so far away from home. The chorus section was haunting:

But it's goodbye now, farewell;

Say goodbye to Okinawa

For today they'll bury you

In West Australia.

You will never be as one

With the Land of the Rising Sun

Sayonara. Sayonara, Nakamura.

We will never know why Hank chose that song other than the fact that he liked it. Yet for me I felt like Hank was bidding farewell to us all. Sayonara, Hank. I felt so lucky to get to know you. Thank you and arigato. 
This text taken from The Boy from Boort: Remembering Hank Nelson, Edited by Bill Gammage, Brij V. Lal, Gavan Daws, published 2014 by ANU Press, The Australian National University, Canberra, Australia. 